
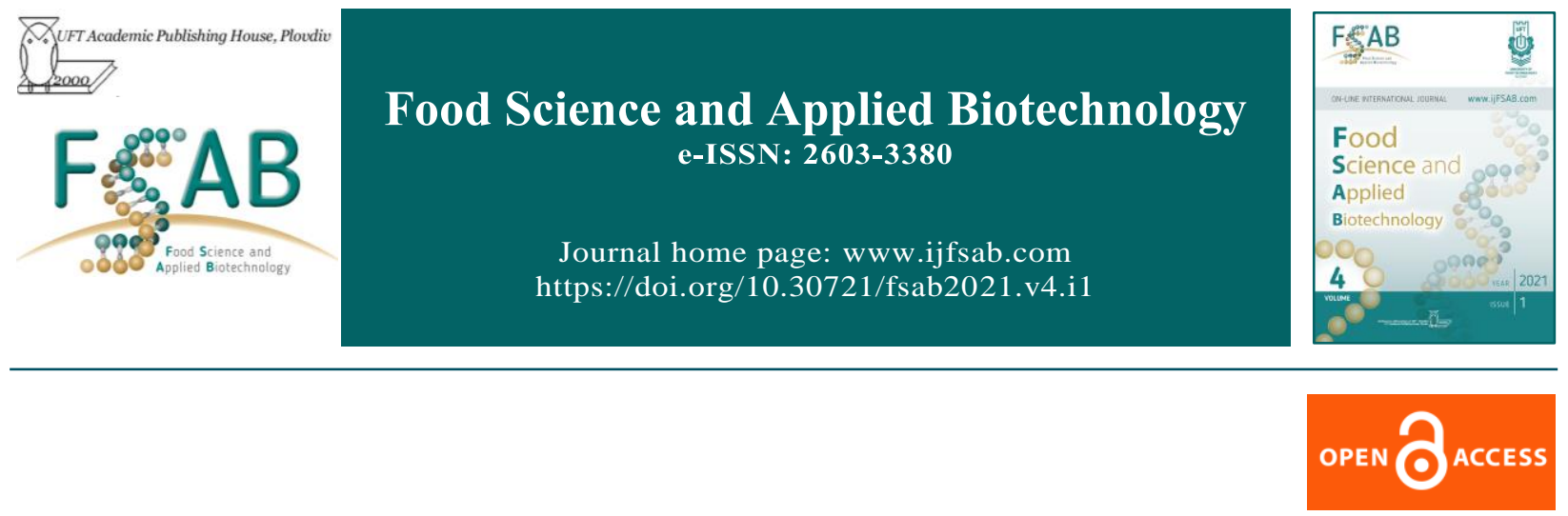

Research Article

\title{
Study on the spread of nematode larvae in fishes marketed in Bulgaria
}

\author{
Yordan Gogov $^{1}$, Gergana Krumova-Valcheva ${ }^{1 \varpi}$ \\ ${ }^{1}$ National Diagnostic and Research Veterinary Medicine Institute, Sofia, Bulgaria
}

\begin{abstract}
The study on the spread of visible nematode larvae in frozen and fresh ocean and sea fish, marked in Bulgaria, has been conducted during the period 2017-2020. A total of 222 whole fish with head and offal (132 - frozen and 90 - fresh) were collected. The analyses were performed in accordance with Regulation (EC) 2074/2005. Presence of visible nematode larvae with sizes from 3 to $11 \mathrm{~mm}$ was found mainly on the walls of the abdominal cavity and the black membrane (94\%) and less frequently on the genitals (3\%). In the frozen fish was found only dead nematode larvae, but in the fresh fishes - alive. The prevalence of nematodes reaches to $100 \%$ and the intensity of invasion varied from 1 to 25 larvae in the mackerel. In the case of fresh sprat, the extension invasion was in the range of 13 to $100 \%$ and the intension invasion from 1 to 58 larvae. In the sample from hake, the prevalence of nematode larvae was 40-100\% and the intensity of the invasion - from 1 to 16 larvae. $50 \%$ of the horse mackerel was infected with 1 to 6 parasites. The highest degree of intensity was found in fresh sprat, where the number of nematode larvae reaches 58 . The health standards for fishery products, introduced by Regulation (EC) No 853/2004 do not allow infected fish with visible parasites to be marketed in the Community. The presence of live nematodes in fish creates a potential health risk to public health.
\end{abstract}

Keywords: visible nematode larvae, frozen fish, chilled fish, intensity of invasion, health risk

Abbreviations: WHO - Word Health Organisation

${ }^{\square}$ Corresponding author: Chief Assist. Prof. Dr. Gergana Krumova-Valcheva, National Diagnostic and Research Veterinary Medicine Institute, 15 Pencho Slaveikov Blvd., Sofia, 1606, Bulgaria, tel.: +359878 489977 e-mail:dr.krumova_vulcheva@abv.bg

\section{Article history:}

Received 11 November 2020

Reviewed 21 February 2021

Accepted 23 February 2021

Available on-line 19 March 2021

https://doi.org/10.30721/fsab2021.v4.i1.125

Gogov and Krumova-Valcheva, 2021

(C) 2021 The Authors. UFT Academic publishing house, Plovdiv

Study on the spread of nematode larvae in fishes marketed ... 


\section{Introduction}

The fish is valuable food and an important source of animal protein for majority of word population (Gutierrez et al. 2011). Moreover, in certain cases, the fish could be carrier of different pathogenic bacteria and parasites that pose a danger for the consumer's health. In 2012, WHO reported over 56 million cases of parasitic invasions in humans related to consumption of fish products (WHO 2012).

The main group of parasites, associated with foodborne outbreak is the nematodes of the family Anisakidae, which includes genera Anisakis, Contracaecum and Hysterothylacium (Smith and Wooten 1978; Shamsi 2019). It is known that they are commonly founding in marine and oceanic fish and have the ability to cause severe pathologies in humans (Pampiglione et al. 2002). Diseases are most often associated with consumption of raw or undercooked fishes, various types of salted, ripped or smoked fishes, as well as fish dishes shaped as "sushi". In many cases dead nematode larvae are found. They are unable to cause human infection, but they could be allergens and causing a serious allergic reaction especially in more sensitive people if they are present in significant quantities (Audicana et al. 2002).

The herring is considered to be a main fish species associated to foodborne anisakidosis in Europe. Furthermore, cases of disease after consumption of contaminated hake, anchovy, mackerel and cod were reported (Ibukun et al. 2019).

A report of mass invasion with anisakide larvae in mullet and anchovy in South Australia was reported in 2010. Intensity of the invasion reached to 112 larvae in one fish (Shasmsi et al. 2010). Similar data are reported by Gebreegriabher et al. (2020). The authors identified larvae of Contracaecum spp. in $49 \%$ of the fishes.

In order to prevent and control the parasitic disease due to fish and fish products, the health standards in Regulation (EC) № 853/2004 laying down not place fishery products that are obviously contaminated with visible parasites on the market. According to the opinion of EFSA (2010), the processing such as cold smoking, pickling or salting are not always sufficiently effective to destroy nematode larvae.
Simat and Trumbic (2019) are shown that some techniques of pickling could be destroying the larvae of Anisakis spp., if the fishes have not been frozen. Dry salting is the effective way to destroy of nematode larvae, but additional efforts are needed to detect and remove them. The allergens of parasites may be present in the fish products even after their killing. The anisakide larvae in fish are widespread and the awareness of producers for their existence in fish is an important point in the strategy of effective prevention. Therefore, the recommendation to frozen of the fish at $-20^{\circ} \mathrm{C}$ for at least 24 hours is very important (Regulation (EC) 853/2004; EFSA 2010).

In practice there are various methods for the detection of nematodes in fish. The modern molecular biological methods are still limited use in routinely parasitological examination of the fish. (Cavallero et al. 2012; Anshary et al. 2014; Mladineo and Poljak 2014). A comparative study of visual methods, light illumination of the fillets and UV-lights indicates that these techniques is not sufficiently efficient for detection of nematode larvae in frozen fish fillets (Levsen et al. 2005). Visual inspection of abdominal cavity and offal of fish for now remains a major diagnostic due to the uncertainty of the developed modern laboratory methods for the detection of nematode larvae. This method is also recommended by European legislation (Regulation (EC) № 2074/2005).

The aim of the present study was to determine the prevalence of nematode larvae in most frequently fishes, offered on the Bulgarian market.

\section{Materials and Methods}

The survey was conducted in 2017-2020 on 222 chilled and frozen fish sold on the Bulgarian market. Frozen fish was 132 including: Norwegian mackerel (Scomber scombrus), autumn catch - 102; black sea sprat (Sprattus sprattus sulinus), spring catch -20 and hake (Merluccius bilinearis), winter catch -10 . Another 90 fishes were chilled: Black sea sprat (Sprattus sprattus sulinus), spring-summer catch 47; Black sea horse mackerel (Trachurus mediterraneus ponticus), spring-summer catch 10; Black sea toad goby (Mesogobius batrachocephalus), spring-summer catch - 10; sea bream (Sparus aurata), spring-summer catch - 6; Atlantic chub mackerel (Scomber japonicus colias), 
summer catch -7 and red mullet (Mullus barbatus ponticus), spring-summer catch -10 .

The tests for visible parasites were carried out in accordance to the method, described in Regulation (EC) № 2074/2005.

\section{Results}

The results on the spread of nematode larvae in frozen and chilled fishes are present in Table 1. Visible parasites were found in 5 of 8 fish species, included in the study: mackerel (Scomber scombrus), sprat (Sprattus sprattus sulinus), hake (Merluccius bilinearis), horse mackerel (Trachurus mediterraneus ponticus) and chub mackerel (Scomber japonicus colias). In three fish species is not detected visible parasites: toad goby
(Mesogobius batrachocephalus), sea bream (Sparus aurata) and red mullet (Mullus barbatus ponticus).

Extensity of invasion up to $100 \%$ was registered in mackerel (Scomber scombrus), sprat (Sprattus sprattus sulinus), and hake (Merluccius bilinearis). The lowest extension of invasion was founded in horse mackerel (Trachurus mediterraneus ponticus) - $50 \%$ and chub mackerel (Scomber japonicus colias) $-29 \%$.

It is interesting to note that the extensity of invasion in chilled sprat (Sprattus sprattus sulinus) reached to $100 \%$, while in frozen sprat (Sprattus sprattus sulinus) it does not exceed $20 \%$.

Table 1. Occurrence of nematode larvae in frozen and chilled fishes

\begin{tabular}{|c|c|c|c|c|}
\hline Fish species & $\begin{array}{l}\text { Number of } \\
\text { examined fish }\end{array}$ & $\begin{array}{c}\text { Number of } \\
\text { infected fish }\end{array}$ & $\begin{array}{l}\text { Number of fish in which is } \\
\text { not detected visible parasites }\end{array}$ & $\begin{array}{l}\text { Extension of } \\
\text { invasion, \% }\end{array}$ \\
\hline \multicolumn{5}{|c|}{ Frozen fish } \\
\hline $\begin{array}{l}\text { Mackerel } \\
\text { (Scomber scombrus) }\end{array}$ & 102 & 48 & 54 & 47 \\
\hline $\begin{array}{l}\text { Sprat } \\
\text { (Sprattus sprattus sulinus) }\end{array}$ & 20 & 2 & 18 & 10 \\
\hline $\begin{array}{l}\text { Hake } \\
\text { (Merluccius bilinearis) }\end{array}$ & 10 & 7 & 3 & 70 \\
\hline Total & 132 & 57 & 75 & 43 \\
\hline \multicolumn{5}{|c|}{ Chilled fish } \\
\hline $\begin{array}{l}\text { Sprat } \\
\text { (Sprattus sprattus sulinus) }\end{array}$ & 47 & 22 & 25 & 47 \\
\hline $\begin{array}{l}\text { Horse mackerel } \\
\text { (Trachurus mediterraneus } \\
\text { ponticus) }\end{array}$ & $s$ & 5 & 5 & 50 \\
\hline $\begin{array}{l}\text { Toad goby (Mesogobius } \\
\text { batrachocephalus) }\end{array}$ & 10 & - & 10 & 0 \\
\hline $\begin{array}{l}\text { Red mullet (Mullus } \\
\text { barbatus ponticus) }\end{array}$ & 10 & - & 10 & 0 \\
\hline $\begin{array}{l}\text { Chub mackerel (Scomber } \\
\text { japonicus colias) }\end{array}$ & 7 & 2 & 5 & 29 \\
\hline Sea bream Sparus aurata) & 6 & - & 6 & 0 \\
\hline Total & 90 & 29 & 61 & 32 \\
\hline
\end{tabular}


Most nematode larvae were found in mackerel (48\%), sprat (24\%), hake (7\%), horse mackerel $(5 \%)$ and chub mackerel (2\%) of all examined fish $(\mathrm{n}=222)$ (Fig. 1).

The intensity of infection in different fish species is demonstrated in Table 2. It varied from 1 to 58 nematode larvae in individual fish. The highest level of invasion was founded in sprat (Sprattus sprattus sulinus): from 1 to 58 parasites and mackerel (Scomber scombrus): from 1 to 25 parasites. The lowest intensity of invasion was provided in horse mackerel (Trachurus mediterraneus ponticus): from 1 to 6 parasites and chub mackerel (Scomber japonicus colias): from 2 to 8 parasites. The number of nematode larvae in one chilled sprat reached high level, while in frozen fish is founded only $1-2$ nematode larvae in one fish. Higher intensity of invasion was found in fish species with higher percent of extensity.
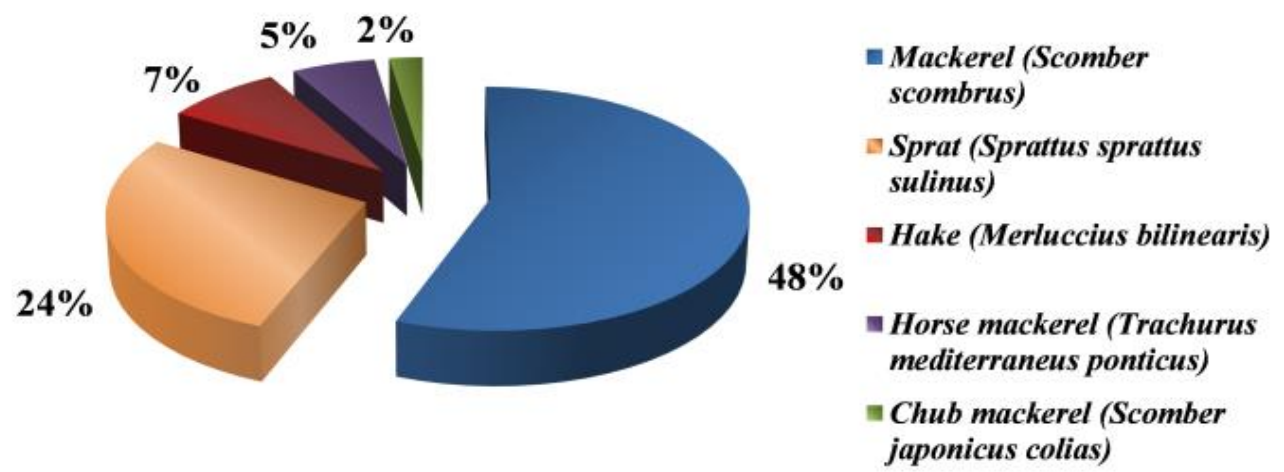

Figure 1. Occurrence of nematode larvae $(\%)$ in different of studied fish species

NOTE: the fish species: sea bream (Sparus aurata), toad goby (Mesogobius batrachocephalus) and red mullet (Mullus barbatus ponticus) are not included in figure, because visible parasites are not detected in them.

Table 2. Intensity of invasion in chilled and frozen fish where there was presence of nematode larvae.

\begin{tabular}{lcccc}
\hline \multirow{2}{*}{ Fish species } & \multicolumn{2}{c}{ Frozen fish } & Chilled fish \\
\cline { 2 - 5 } & $\begin{array}{c}\text { Total } \\
\text { number }\end{array}$ & $\begin{array}{c}\text { Intensity of invasion } \\
\text { (number of nematode larvae) }\end{array}$ & $\begin{array}{c}\text { Total } \\
\text { number }\end{array}$ & $\begin{array}{c}\text { Intensity of invasion } \\
\text { (number of nematode larvae) }\end{array}$ \\
\hline Mackerel (Scomber scombrus) & 48 & $1-25$ & - & - \\
$\begin{array}{l}\text { Sprat } \\
\begin{array}{l}\text { Sprattus sprattus sulinus) } \\
\text { Hake }\end{array}\end{array}$ & 2 & $1-2$ & 22 & $1-58$ \\
$\begin{array}{l}\text { Merluccius bilinearis) } \\
\text { Horse mackerel (Trachurus } \\
\text { mediterraneus ponticus) }\end{array}$ & 7 & $1-16$ & - & - \\
$\begin{array}{l}\text { Chub mackerel (Scomber } \\
\text { japonicus colias) }\end{array}$ & - & - & 5 & $1-6$ \\
\hline
\end{tabular}


The nematode larvae were found mainly on the walls of abdominal cavity and black membrane. The visible nematode larvae were found on the surface of genitals only in $3 \%$ of the cases. They usually observed in the spiral form with different length (on average about $11 \mathrm{~mm}$ ) (Fig.2).

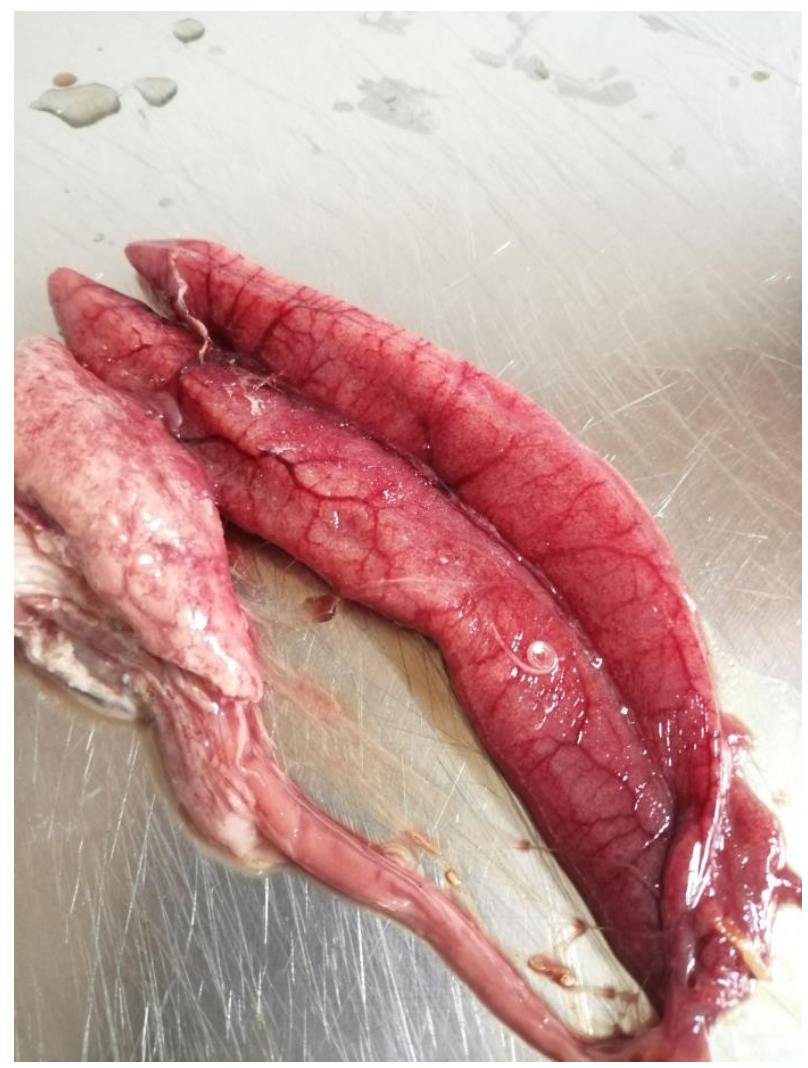

Figure 2. Nematode larvae founded on the walls of the gonads

The larvae are single or in group, covered with capsule of connective tissue. The migration of nematode larvae to the gonads surface was found only in mackerel. No nematode larvae were found in the musculature in any of the studied fishes.

Visible nematode larvae with spontaneous movement and sights of vitality were found in 22 chilled fish - sprat, 5 in horse mackerel and 2 in chub mackerel. Live nematode larvae were not found in frozen fish.

\section{Discussion}

The obtained data on the prevalence of visible nematode larvae in various fish species confirm our previous findings (Gogov and Krumova-Valcheva 2014). The tendency for the most frequent detection of parasites in the abdominal cavity of frozen mackerel is preserved. Unlike the previous study, now there is a tendency for increase of the intensity of invasion. The data reported by a number of researchers are similar. For example, Gebregziabher et al. (2020) reported a parasitic invasion in $30 \%$ of the studied fishes. Other authors reported an invasion in fish exceeding $50 \%$ (Chen and Shin 2015). High level of extension of invasion (up to 90 $\%$ ) was showed in study for the prevalence of genus Anisakis in sea fish from Indonesia (Anshary et al. 2014). The conclusion of some authors that the mackerel is a common fish species contaminated with nematode larvae is also confirmed (Levsen et al. 2005; Chen and Shin 2015; Arafa et al. 2019). These fish species is often associated with cases of human anisakidosis (Asato et al. 1991; Arizono et al. 2012). Anisakidosis is human disease and caused by larval forms of nematodes belonging to the family Anisakidae. Anisakis simplex and Pseudoterranova decipiense cause more often these infections. The clinical simptoms of human disease are manifested by the larval migration in stomach and intestine walls. They characterized with mild to severe abdominal pain, indigestion, nausea, vomiting and sometimes with hypersensitivity reaction such as urticaria, angoedema and anaphylaxis (Torgerson and Macpherson 2011). The stomach anisakiosis is commonly related to members of genus Pseudoterranova, while intestinal anisakiosis with species of the genus Anisakis.

The definitive hosts of anisakide larvae are marine mammals and sometimes birds, where the nematodes are found in intestinal tract. The analysis of the spread of Anisakis spp. identified with molecular methods suggested the occurrence of species-specific patterns of distribution related with occurrence of the definitive hosts (Kuhn et al. 2011).

The data of the topographic spread of nematode larvae in tested fish show dominating invasion in abdominal cavity, intestine surface and gonads. In contrast, Suzuki et al. (2010) found nematode larvae in the muscle more frequently than in abdominal cavity. Our study indicates the absence of nematode larvae in fish muscle. It gives us no reason to assume that the health risk is eliminated. However, it should be noted that the evisceration of fish and appropriated freezing are important factors against 
the migration to the fish muscles (Cipriani et al. 2015).

The presence of live nematode larvae in chilled fish, marketed in Bulgaria, represents a certain health risk in the preparation of homemade fish dishes. In addition, the traditional consumption of sprat in Bulgaria without fish evisceration and eating of whole undercooked fish would be pose a risk even in the present of only dead parasites. The dead nematode larvae could be caused a clinical manifestation of food allergy in the consumers (Aibinu et al. 2019).

\section{Conclusions}

The current study shows that nematode larvae are common find in main fish species marketed in Bulgaria. The deep frozen of the fish (especially those eat raw) is an effective method of disposing of live nematode larvae and preventing anisakidosis in humans. Nevertheless, the potential risk of food allergies should not be underestimated.

The problem with widespread of nematode larvae in industrial fish species requires systematic monitoring by business operators and by competent authority. Compliance of national and European legislation regarding the safety of fish offered on Bulgarian market. The information observed by monitoring could be used for risk assessment in food chain.

\section{References}

Aibinu E.I., Smooker M.P., Lopata L.A. Anisakid nematodes in fish and shellfish - from infection to allergies. International Journal for Parasitology: Parasite and Wildlife, 2019, 9(8): 384-393. https://doi.org/10.1016/j.ijppaw.2019.04.007

Anshary H., Sriwulan, Freeman M.A., Ogawa K. Occurrence and molecular identification of Anisakis Dujardin, 1984 from marine fish in Southern Makassar Strait, Indonesia. Korean Journal Parasitology, 2014, 52(1): 9-19. https://doi.org/10.3347/kjp.2014.52.1.9

Arafa W., Hassan A., Mahrous L., Abdel-Ghany A., Aboelhadid S. Occurrence and molecular characterization of zoonotic Aniskais simplex sensu sticti and Anisakis pegreffii larve in retail-marketed fish. Journal of Food Safety, 2019, 39(5): e12682. https://doi.org/10.1111/jfs.12682

Arizona N., Yamada M., Tegoshi T., Yoshikawa M. Anisakis simplex Sensu stricto and Anisakis pegreffii: biological characteristics and pathogenetic potential in human anisakiasis. Foodborne Pathogens and Disease, 2012, 9(6): 517-521. https://doi.org/10.1089/fpd.2011.1076

Asato R., Wakura M., Sneyoshi T. A case of human infection with Anisakis physeteris larvae in Okinawa, Japan. Japanesse Journal of Parazitology, 1991, 40(2): 181-183.

https://jglobal.jst.go.jp/en/detail?JGLOBAL_ID=200 902099374518915

Audicana M.T., Ansotegui I.J., Fernandes de Corres L., Kennedy M.W. Anisakis simplex: dangerous - dead and alive? Trends Parasitology, 2002, 18(1): 20-25. https://doi.org/10.1016/s1471-4922(01)02152-3

Cavalleros S., Ligas A., Bruschi F., D'Amelio S. Molecular identification of Anisakis spp. from fishes collected in the Tyrrhenian Sea (NW

Mediterranean). Veterinary Parasitology, 2012, 187(3-4): 563-566. https://doi.org/10.1016/j.vetpar.2012.01.033

Chen H., Shin H. Occurrence and prevalence of fishborne Anisakis larve in the spotted mackerel Scomber australasicus from Taiwanese waters. Acta Tropica, 2015, 147(5): 61-67.

https://doi.org/10.1016/j.actatropica.2015.02.011

Cipriani P., Smaldone G., Acerra V., D'Angello L., Anastasio A., Bellisario B., Palma G., Cheleschi R., Nasseetti G., Mattiucci S. Genetic identification and distribution of the parasitic larvae of Anisakis pegreffi and Anisakis simplex (s.s.) in European hake Merluccius Merluccius from Tyrrhenian Sea and Spanish Atlantic coast: implications for food safety. International Journal of Food Safety, 2015, 198(4): 1-8. https://doi.org/10.1016/j.ijfoodmicro.2014.11.019

Commission Regulation (EC) No 2074/2005 of 5 December 2005 laying down implementing measures for certain products under Regulation (EC) No 853/2004 of the European Parliament and of the Council and for the organisation of official controls under Regulation (EC) No 854/2004 of the European Parliament and of the Council and Regulation (EC) No 882/2004 of the European Parliament and of the Council, derogating from Regulation (EC) No $852 / 2004$ of the European Parliament and of the Council and amending Regulations (EC) No 853/2004 and (EC) No 854/2004 (Text with EEA relevance). Journal of the European Communities, 2005, L 338/27. http://data.europa.eu/eli/reg/2005/2074/oj

European Food Safety Authority (EFSA). Panel on Biological Hazards (BIOHAZ), Scientific opinion on risk assessment of parasites in fishery products. EFSA journal, 2010, 8(4): 1543. https://doi.org/10.2903/j.efsa.2010.1543

FAO yearbook. Fishery and aquaculture statistics 2017/FAO annuaire. Statistique despeches et de 
l'aquaculture 2017/FAO anuario. Estadisticas de pesca y acuicultura 2017. Rome/Roma. 2019. eBook ISBN: 978-92-5-131669-6

Gebregziabher H., Degefy H., Tsegay A.K. Prevalence of internal helminth parasites of fish in Gilgel-Gibe river and three selected ponds in and around Jimma Town, South West Ethiopia. Turkish Journal of Fish and Aquatic Sciences, 2020, 20(9), 693-699. https://doi.org/10.4194/1303-2712-v20_9_04

Gogov Y., Krumova-Valcheva G. Studies on spread of nematodes of fam. Anisakidae in marine and freshwater fish. Proceedings of the National Congress of Medical Geography, Sofia, Proceedings of the Union of Medical Societies and the Bulgarian Society of Medical Geography, Sofia, Bulgaria, 2014, pp. 230-244. ISNN 1314-5096. [In Bulgarian]

Gutierez N.L., Hilborn R., Defeo Q., Leadership social capital and incentives promote successful fisheries. Nature, 2011, 470(1): 386-389. https://doi.org/10.1038/nature09689

Kuhn T., García-Màrquez J., Klimpel S. Adaptive Radiation within Marine Anisakid Nematodes: A Zoogeographical Modeling of Cosmopolitan, Zoonotic Parasites. PLoS ONE, 2011, 6(12): e28642. https://doi.org/10.1371/journal.pone.0028642

Levsen A., Lunestad B.T., Berland B. Low detection efficiency of candling as a commonly recommended inspection method for nematode larvae in the flesh of pelagic fish. Journal of Food Protection, 2005, 68(4): 828-832. https://doi.org/10.4315/0362-028x$\underline{68.4 .828}$

Mladineo I., Poljak V. Ecology and genetic structure of zoonotic Anisakis spp. from Adriatic commercial fish species. Applied and Environmental Microbiology, 2014, 80(4): 1281-1290. https://doi.org/10.1128/AEM.03561-13

Pampiglione S., Rivasi F., Criscuolo M., De Benedictis A., Centile A., Russo S., Testini M., Villan M. Human anisakiasis in Italy: a report of eleven new cases. Pathology Research Practice, 2002, 198(6): 429-434. https://doi.org/10.1078/0344-0338-00277

Regulation (EC) No 853/2004 of the European Parliament and of the Council of 29 April 2004 laying down specific hygiene rules for on the hygiene of foodstuffs. Official Journal of the European Communities, 2004, L 139/55. https://eurlex.europa.eu/legalcontent/en/ALL/?uri=CELEX\%3A32004R0853

Shamsi S., Eisenbarth A., Saptarshi S., Beveridge I., Gasse R., Lopata A. Occurrence and abundance of anisakid nematode larvae in five species of fish from Southern Australian waters. Parasitology Research, 2010, 108(10): 927-934. https://doi.org/10.1007/s00436-010-2134-1
Shamsi S. Seafood-borne parasitic diseases: A "OneHealth" approach is need. Fishes, 2019, 4(1): 9. https://doi.org/10.3390/fishes4010009

Simat V., Zeljka T. Viability of Anisakis spp. larvae after direct exposure to different processing media and non-thermal processing in Anchovy fillets. Fiches, 2019, 4(1): 19. https://doi.org/10.3390/fishes4010019

Smith J.W., Wooten R. Anisakis and anisakiasis. Advanced Parasitology, 1978, 16(1): 93-163. https://doi.org/10.1016/S0065-308X(08)60573-4

Suzuki J., Murata R., Hosaka M., Araki I. Risk factors for human Anisakis infection and association between the geographic origins of Scomber japonicas and anisakid nematodes. International Journal of Food Microbiology, 2010, 137(1): 88-93. https://doi.org/10.1016/j.ijfoodmicro.2009.10.001

Torgerson P.R., Macpherson C.N.L. The socioeconomic burden of parasitic zoonoses: Global trends. Veterinary Parasitology, 2011, 182(1): 79-95. https://doi.org/10.1016/j.vetpar.2011.07.017

World Health Organisation. Soil transmitted helminths. World Health Organisation, 2012. Available at: http://www.who.int/intestinal_worms/en/ 